\title{
The construction of masculinity in male facial care product advertisement
}

\author{
Billy K. Sarwono ${ }^{1,{ }^{*}}$ and Alifia Oktrina Fayardi ${ }^{1}$ \\ ${ }^{1}$ Department of Communication Science, FISIP Universitas Indonesia, Indonesia
}

\begin{abstract}
Many studies are done on gender bias on women, but a little on men. If one of women's stereotypes is wearing makeup, then one of men is no need taking care of his face. However, the consumption of male facial products has shown an up going trend. Ironically, it is not commonly perceived as users of facial care products, since they would be labeled as gay. This study aims to show that gender bias does not only happen to women but also men. In addition, the media is supposed to be the means to liberate and empower marginalized groups and not present news by reinforcing stereotypes of the group. The research question is how ads construct a masculine figure by emphasizing on his needs for facial treatment? The theoretical concepts used in this research are social construction of reality, stereotypes and fetishism while the method of data collection is semiotic text analysis through purposive selection. The results show that masculinity represented in the advertisement figures defines the stereotypes that fit with consumptive urban society behavior. Construction of the advertised product is not for the purpose of selling it for its function, but rather to support the exclusive image and identity of the target buyers.
\end{abstract}

\section{Introduction}

The Vice Governor of DKI Jakarta, Sandiaga Uno was captured applying lip moisturizer in a formal public appearance he made with the Governor, on December 13, 2017. This event went viral on the media, because the action was deemed unusual by most Indonesians as lipsticks are mostly associated with women. And also, due to the high level of humidity in Jakarta, lip balm is believed to be unnecessary.

Here are two of several news headlines on online media that questioned Uno's act: The first headline is, 'Why is Sandiaga Uno Using Lip Moisturizer? [1]; and, 'Guys Like Sandiaga Uno Use Lip Moisturizer, Must He?' [2].

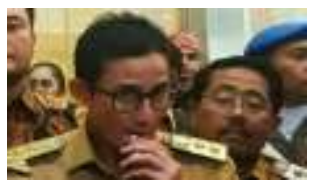

Fig. 1. The picture of Jakarta Vice Governor that went viral.

\footnotetext{
${ }^{*}$ Corresponding outhor : billysarwono@gmail.com
} 
Regardless of the need for Uno to use a lip moisturizer, it can be implied that the media questioned the masculinity of the official. This media reaction is understandable, given the general perspective that most feminine men belong to the gay group, which remains to be a hot topic, as different sexual orientations are still considered inappropriate by the society. Some people even think that this group needs to seek for religious guidance [3]. The main discourse that continues to prevail in the public is that men should be masculine while women should be feminine, and this is because the community sees these characteristics as identical with sex. Hofstede [4] and others describe some of the following male characteristics: aggressiveness, material success and strength, physical strength, heterosexuality, emotional control, authoritativeness toward women, contained in a masculine figure who is muscular, powerful, social, highly competitive and strong in leadership. Conversely, women are stereotyped with gentleness and they are good at doing things which require carefulness and neatness, so the best work areas that are suitable for them are those which match the characteristics they are assumed to have.

Ourahmoun and Nyeck [5] explain that feminine and masculine values cannot be fragmented, cannot be contrasted, but feminine and masculine meanings are blurred constructions, subject to the context they are related to. Stuart Hall, Evans \& Nixon [6] argue that although the masculine concept shows dominance over women, it also constitutes a burden for men. According to them, masculinity is not something fixed and the concept of masculinity is a cultural one that is attached to: "attributes, capacities, dispositions and forms of conduct at a given historical moment which are then invented and constructed".

In relation to the societal context of society in Indonesia, Clark [7] explains that the Soeharto government, 1965-1998, kept men "on their right track" by instilling a heterosexual gender ideology as the ideal family structure which perceives the perfect family as one that is within a happy and healthy marriage. The emergence of the homosexual phenomenon, in that era, was considered a threat to the identity of men and society, because it created a sense of shame and can tarnish the identity of normal men as perceived by the majority of the people. The impact of the strengthening of cultural values is still felt today, so those who do not follow the standard of patrilineal culture are considered to be irreverent, and even considered to have gone against religion.

While most people doubt the masculinity of the users of facial care products, the Nielsen survey, in Indonesia [8], shows the market share of male grooming has reached 23 percent and this makes up 20 percent of the total market share of self-care products. The increase continues to be supported by a brand that launches special care products for men including the Japanese SK II back in 1983 and Amway America in 2015. Simpson [9] explains the challenges for the marketing of conventional or heterosexual male products which do not seem to be promising. In order for self-care products to be more and more accepted, various cosmetic products for men were labelled specially to give some sense of masculinity, for example by using the term guyliner for eyeliner manbag for handbag; mankup for makeup; manscara for mascara; etc.

Stuart Hall [10] explains that the media does not reflect reality and replace the media function with the proposition that the media message inflects popular consciousness in the ideologically approved directions. The media 'effect' is theorized as putting a particular gloss on reality that creates virtual circle between constructed messages and preferred reading. Based on this thought, the research question here is how ads construct a masculine figure by emphasizing on his needs for facial treatment? This study aims to show that gender bias does not only happen to women but also men, and to inspire the media people to reduce the bias in achieving Sustainable Development Goals. 


\section{Literature review}

In the late 1990s, a study by Matthew Hall [11], suggests that men's lifestyle magazines become one of the pioneers of new spaces for different masculine representations: men becoming almost as caring as women in their business appearance and self-care activities. This phenomenon sparked a debate about the feminization of men or new masculinity [12]. Later, the term shifts to metrosexuals to eliminate the stigma that men who dress up are gay [13]. Several previous studies in Indonesia $[14,15]$ explain that metrosexual groups are present in urban communities. They are the upper middle class executives, whose profession and job demands an attractive appearance; therefore, they tend to have a lifestyle that increasingly seeks for a clean, clammy face. To get that image, they do not hesitate to use facial care products (moisturizers, facial cleansers, lip balm, eye cream and others), do exercise in the fitness centers, spend enough money to increase prestige.

The emergence of metrosexual groups in urban communities and male skin care products users of course cannot be separated from the development of industry and global media, particularly the role of advertising in the media. Studies on the effects of male grooming products on the public show varying results, such as the presence of significant and positive influence [16], affecting youth when advertising becomes part of a natural cultural life [17], and ads producers create dialectics that encourage men to become consumers of feminine-style products, but let them retain the quality of traditional masculinity [18].

Piliang [19] argued that advertising had become a media that cannot be separated from people lifestyle: it became a lifestyle setter, and what is more it often conveyed a false reality rather than the real life. According to Piliang, advertising constructs the consumer society into a lifestyle group that is organized on a certain pattern. Therefore, it can be said that the ad has a certain strength or charm in constructing how a product has the power or charm so that its audience feel that what the ad represents is the ideal image, the standard norms that apply, for example; the commodity fetishism carried out by advertising through images of imagery and language, can lead every individual to false consciousness.

The theoretical conception of the construction of social reality used in this study refers to the thinking of Berger and Luckmann [20]. McQuails [21] clarifies Berger and Luckmann's thinking that a person feels the world in which he lives as something real that is beyond the reach of his perceptions and beliefs, and this is not simply because people feel the reality through what he sees and feels, but his perception of a reality will have an impact on what he does in relation to others. In social interaction, the person will produce and reproduce what he believes to be reality. So that reality is not just there, but it is constructed by the media, society and the reality itself.

\section{Research methods}

The research method chosen is semiotics, because in semiotics, representation is used as a way to understand value transmission through media. Rose [22] explains that semiotics analysis in advertising needs to take into account several things such as: what it represents, what values are associated with the brand and strategy used, and how the advertiser make assumption about the target audience and tries to attract them. Furthermore, she suggests exploring what the signs might symbolize, for example: representation of bodies, behavior, activity, a uniqueness or settings, all of which cannot be separated from the cultural context.

The semiotics analysis method used refers to Peirce's thinking [23]. In this research, researchers chose the 'Garnier Men' face-care ad [24], starring Joe Taslim, because Joe has track records as a national karateka team membered, and have had experience working in a Hollywood film: Fast and Furious, so he has fans domestically and in Japan and Korea. 
There are several ads for the same product, but the researcher chose the 'Garnier Men Turbolight Oil Control' advertisement, because the activities shown were more varied. The observation unit in this research is a visual audio sign in the scene cuts contained in the character of a metrosexual figure. While the analysis unit is the character depicted in the advertisements and activities performed by the artist in the ad. As an Indonesian, the researcher interprets the Garnier brand as a name that comes from an opera House in Paris which was founded from 1861-1875 and has 1979 seats. Its stylized architectural style, well known in the 19th and 20th centuries, also shows the magnificence of the buildings and the functions up to now.

Goodness criteria this research use three criteria applicable to qualitative research: credibility transferability and comfortability. The weakness of this research is that there is only one selected research object, so it affects the volume of data obtained. In addition, researchers did not conduct interviews with target audiences that could enrich the analysis of the meaning of their cultural values that are represented in the ads.

\section{Findings}
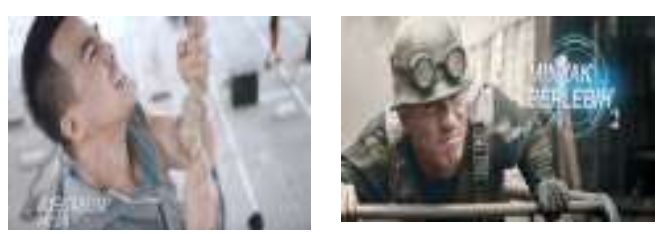

Fig. 2. A sport \& adventure person.

Figure 2: Workout activities at the fitness center, and Joe is on a speeding car in the arena of war. He wore a helmet complete with bulletproof vests; all of which made his face so oily as shown by the sign 'TOO MUCH OIL'
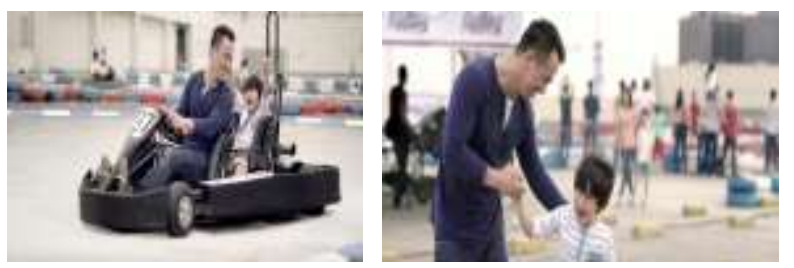

Fig. 3. A family man.

Figure 3: Together with a 7-year-old kid riding a kart in a go-karting arena. In this scene, Joe turns to his son, and his son appears lifting both hands that express the joy of winning a kart match.

Figure 3: On the edge of the karting rink, Joe holds the child's hand and taps the child's shoulders depicting the pride of their success. There was also a woman walking while holding a child's shoulders, and there was a crowd of other spectators, and a woman standing between a man and a child, with another man holding a small child. 

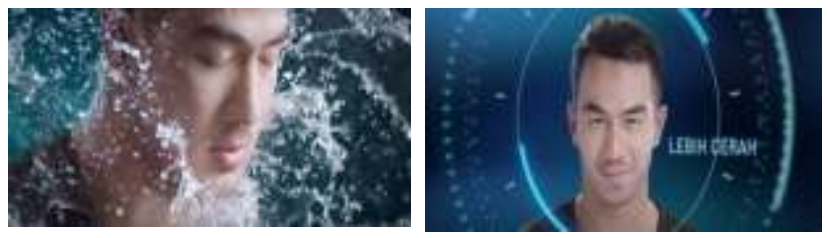

Fig. 4. A Garnier man.

Figure 4: Joe's face washes his face in a water spray, with a calm, relaxed face. And blue circles around the face depicting the aura, in an older, grayed-up blue background and a bright face pointed out with a smile of freshness and satisfaction.

Table 1. Results of data analysis based on peirce semiotics application.

\begin{tabular}{|l|l|l|}
\hline \multicolumn{1}{|c|}{ Sign } & \multicolumn{1}{|c|}{ Object } & \multicolumn{1}{c|}{ Interpretant } \\
\hline $\begin{array}{l}\text { A muscular } \\
\text { Garnier man }\end{array}$ & $\begin{array}{l}\text { Heavy Sport: lifting one's body using } \\
\text { rope (Fig 2) }\end{array}$ & $\begin{array}{l}\text { Men maintain their fitnes and are } \\
\text { strong, it is a stereotype of men's } \\
\text { character }\end{array}$ \\
\hline $\begin{array}{l}\text { The Shooting } \\
\text { Scene from an } \\
\text { action film }\end{array}$ & $\begin{array}{l}\text { Shooting gears } \\
\text { (Fig 2) } \\
\text { Flames, a big motorbike, a speeding jeep }\end{array}$ & $\begin{array}{l}\text { Men face challenges and dare to } \\
\text { take risks, it is a stereotype of men's } \\
\text { character }\end{array}$ \\
\hline $\begin{array}{l}\text { Playing with a } \\
\text { kid }\end{array}$ & $\begin{array}{l}\text { Dad and mom are touching the child's } \\
\text { shoulder, and a father who carries a boy } \\
\text { (Fig 3) }\end{array}$ & $\begin{array}{l}\text { Men have a family, it is a stereotype } \\
\text { of normal people }\end{array}$ \\
\hline Garnier Men & $\begin{array}{l}\text { Men clean their face using facial wash } \\
\text { (Images) }\end{array}$ & $\begin{array}{l}\text { Well treated face, attractive } \\
\text { appearance, it is type of today's man }\end{array}$ \\
\hline
\end{tabular}

\section{Discussion and conclusion}

Usually fetishism is associated with a female consumer who tends to be busy making her body and face perfect. However, now it is the same with men. The need for some men to appear like the figure in the picture in media has motivated them to be part of the industrial commodities associated with the activity they appear in and the makeup they wear. Commodities emerge when value owned of a product changes from the value of use to the value of exchange. In general, men clean the face with soap. The emergence of metrosexual lifestyles has make men require certain facial cleansing products. This is how false needs arise: something that is not really needed becomes a necessity that must be met. Here, facial wash product will not just make the face clean, but also reflects the status of a person, depending on the product used and the brand selected. This means that advertising, used as a sample in this research, has either constructed or manipulated, and spread the false need into the lifestyle of young people in big cities. It is likely that the product will be bought not necessarily because of its usefulness, but more because of the the satisfaction or status obtained when using such branded goods. The consumers will then be included in the 
exclusive group, similarly like the Garnier opera house label which is different, classical and elegant if compared to others.

The media have a big role in providing the values and confidence that exist in the patriarchal society, which is to construct the image of an ideal man. Here the media constructs that the figure of Garnier Men, is an ideal figure, different from men in general, because it has a masculine character, handsome, charming, which is the result of regular face care. In addition, the facial care products used also reflect a certain status. What the media do is inseparable from the values and ideology of the dominant group of patriarchal society. Without realizing it, the advertisers participate in maintaining the prevailing habits of the culture because on the daily bases, values and norms have been ingrained inherently in their thinking and behavior, both within the home family, and in the workplace and in the public arena. So the message submitted by the ad producer is also in accordance with the assumption of natural values prevailing in the community. For example, men are supposed to have male characteristics, brave, and also have a family and children. The description of the child in advertising is also important, because the concept of a happy family that is constructed by the media is one that consist ot mother, father and children.

Today, the construction of reality is not only created by the mainstream media, but also by the digital media. Through the advancement of social media as shown in selfie, Instagram, and so forth, many people use social media to improve their status. Research results in Indonesia show that many people from all types of life and age use social media to improve their status. Photos they upload on social media can be considered as something to indicate their status: so many of them go to the fitness center to show their lifestyle, and not because it relates to the primary need for health or fitness. Referring to the thoughts of Luckman \& Berger, as well as Baudillard's fetishism, the production and reproduction of lifestyles of the pseudo metropolitan groups have been internalized in the lives of the metrosexuals, colored by external factors (mainstream media, industry, or social media), leading to the creation of objectivism that today's men lifestyle does not only concern with the problem of masculinity as a prevailing stereotype, but also as a man who takes care of his facial appearance and undergo treatment that used to be done by women. Statistics show that there have been many salons opened for men and the number is growing, although the discourses about men dressing up in society and the media are still ongoing.

With its power, media can construct cultural values by redefining stereotypes according to the culture of the local community and the era of digital media. The results of this research will have more leverage, if in the future further studies on producers and consumers of advertising are conducted. These studies should aim at deepening the understanding of the reality constructed by the producers, and the meaning that is captured by the consumers, whether they can read the media critically, or fail to resist because of the strong patriarchal culture.

\section{References}

1. Kompas. https://megapolitan.kompas.com/rea/2017/12/13/21222361/mengapasandiaga-uno-pakai-pelembab-bibir. (2017) Accessed on 19 Maret 2018

2. Liputan 6. http://health.liputan6.com/read/3194073/cowok-seperti-sandiaga-unopakai-pelembap-bibir-perlukah. (2017). Accessed on 19 Maret 2018

3. Kompas. https://megapolitan.com/read/2018/02/19/13140221/bina-kelompok-lgbtpemkot-depok-bentuk-tim-terpadu. (2016)Accessed 31 Maret 2018

4. DeVito, Joseph A. The Interpersonal Communication Book. 14th edition. Essex CM20 2JE: Pearson Education Limited. 61 (2016)

5. Ourahmoune, Nacima. \& Nyeck, S. "Gender Values and Brand Communication: the Transfer of Masculine Representations to Brand Narratives." E - European Advances 
in Consumer Research. Volume 8, eds. Stefania Borghini, Mary Ann McGrath, and Cele Otnes, Duluth, MN: Association for Consumer Research, 181-188 (2007)

6. Hall, Stuart, Jessica Evans \& Sean Nixon. Representation. 2nd Edition. Thousand Oaks, CA: Sage Publications, (2011)

7. Clark, Marshall. Indonesian Cinema: "Exploring Cultures of Masculinity, Censorship and Violence "in Ariel Heryanto. Pop Culture In Indonesia. Fluid Identities in Post Authoritarian Politics. Indonesian Translated version, translation is done by Eka S Saputra. Yogyakarta: Jalasutra. (2012)

8. Sankhyaadi, Aria. "Survey: Most Male Products Buyers are Women", http://lifestyle.liputan6.com/read/2040750/survei-pembeli-product-personal-pria-mostis-woman-. 23 APRIL, (2014). Accessed on 5 December 2017.

9. Tungate, M. Branded Male: Marketing to Men. New Delhi,: Kogan Page Publishers (2008).

10. Rojek, Chris. "Stuart Hall and the Birmingham School" in Tim Edwards. Cultural Theory. Classical and Contemporary Positions. Thousand Oaks, CA: Sage Publications. (2008)

11. Hall, Matthew, Brendan Gough, Sarah Seymour-Smith. "I'm METRO, NOT Gay!": A Discursive Analysis of Men's Accounts of Makeup Use on YouTube http://journals.sagepub.com/doi/abs/10.3149/jms.2003.209 . Accessed on 1 April 2018.

12. Kurnia, N. 'Masculinity Representation in Advertising'. (2004) Journal of Social Sciences and Political Science Volume 8, Number 1, July 2004. Yogyakarta: Faculty of Social Sciences and Political science.

13. Hall, Matthew. Metrosexual Masculinities. Basinstoke: Palgrave MacMillian. (2015)

14. Ningrum, Widyan Arika. Fenomena Pria Metroseksual di Kota Malang http://karyailmiah.um.ac.id/index.php/sejarah/article/view/729. 2006. Accessed on 1 April 2018

15. Apriliono, Riki. "Representation of Metrosexual Values" in Men's Guide Magazine. https://media.neliti.com/media/publications/188569-ID-representation-valuemetrosexual-di.pdf. (2014). Accessed on April 1, 2018

16. Souiden, N., \& Diagne, M. (2009). "Canadian and French men's consumption of cosmetics: a comparison of their attitudes and motivations". Journal of Consumer Marketing, 26 (2), 97-109. (2009)

17. Ruddock, Andy. Youth and Media. Singapore: SAGE Publications Asia-Pacific Pte. Ltd. (2013)

18. Harrison, Claire . Real men do wear mascara: Advertising discourse and masculine identity. Critical Discourse Studies, 5 (1), 55-74. Taylor \& Francis. (2008)

19. Piliang, Yasraf Amir. Hypersemiotics: Tafsir Cultural Studies On Death Meaning. Yogyakarta: Jalasutra. 63-70 (2003)

20. Berger, Luckmann. The Social Construction of Reality. A Treatise in the Sociology of Knowledge. New York : A Double Day Anchor Book. (1966).

21. McQuails, Dennis. McQuails's Reader in Mass Communication Theory. Thousand Oaks: Sage Publications. 55 (2002)

22. Rose, Gillian. Visual Methodologies. An Introduction to Researching with Visual. (2012)

23. Danesi, Marcel. Message, Signs and Meanings: A Basic Textbook in Semiotic and Communication. Indonesian Translation version. Translatated is done by Gunawan Admiranto. Yogyakarta: Jalasutra. 37-47. 2004

24. https://m.youtube.com/watch? $\mathrm{v}=$ NJyKtWXKaCo. Accessed on February, 2018 